\title{
Distinct Presynaptic Regulation of Dopamine Release through NMDA Receptors in Striosome- and Matrix-enriched Areas of the Rat Striatum
}

\author{
Marie-Odile Krebs, Fabrice Trovero, Marcel Desban, Christian Gauchy, Jacques Glowinski, and Marie-Lou \\ Kemel
}

Chaire de Neuropharmacologie, INSERM U114, Collège de France, 75231 Paris Cedex 05, France

\begin{abstract}
Striosome- and matrix-enriched striatal zones were defined in coronal and sagittal brain sections of the rat, on the basis of ${ }^{3} \mathrm{H}$-naloxone binding to $\mu$-opiate receptors (a striosomespecific marker). Then, using a new in vitro microsuperfusion device, the NMDA $(50 \mu \mathrm{M})$-evoked release of newly synthesized ${ }^{3} \mathrm{H}$-dopamine ( ${ }^{3} \mathrm{H}$-DA) was examined in these four striatal areas under $\mathrm{Mg}^{2+}$-free conditions. The amplitudes of the responses were different in striosomal $(171 \pm 6 \%$ and 161 $\pm 5 \%$ of the spontaneous release) than in matrix areas (223 $\pm 6 \%$ and $248 \pm 12 \%)$, even when glycine (1 or $100 \mu \mathrm{M})$ was coapplied (in the presence of $1 \mu \mathrm{M}$ strychnine). In the four areas, the NMDA-evoked release of ${ }^{3} \mathrm{H}-\mathrm{DA}$ was blocked completely by $\mathrm{Mg}^{2+}(1 \mathrm{mM})$ or (+)-5-methyl-10,11-dihydro5H-dibenzo(a,d)cyclohepten-5,10-imine maleate (MK-801; $1 \mu \mathrm{M})$ and almost totally abolished by kynurenate $(100 \mu \mathrm{M})$. Because the tetrodotoxin (TTX)-resistant NMDA-evoked release of ${ }^{3} \mathrm{H}-\mathrm{DA}$ was similar in striosome- (148 $\pm 5 \%$ and 152 $\pm 6 \%$ ) or matrix-enriched $(161 \pm 5 \%$ and $156 \pm 7 \%)$ areas, the indirect (TTX-sensitive) component of NMDA-evoked responses, which involves striatal neurons and/or afferent fibers, seems more important in the matrix- than in the striosome-enriched areas. The modulation of DA release by cortical glutamate and/or aspartate-containing inputs through NMDA receptors in the matrix appears thus to be partly distinct from that observed in the striosomes, providing some functional basis for the histochemical striatal heterogeneity.
\end{abstract}

Within the basal ganglia, the striatum plays a major role in the processing of sensorimotor and prelimbic cortical inputs. Two anatomical compartments, the striosomes and the matrix, arranged as a mosaic, were initially defined by Graybiel and Ragsdale (1978) as AChE-poor and AChE-rich zones, respectively. These compartments differ in the distribution of numerous neuronal markers, suggesting that the neuronal populations are different in each area. For instance, the striosomes are rich in $\mu$-opiate receptors (Herkenham and Pert, 1981) and M1 muscarinic cholinergic receptors (Nastuk and Graybiel, 1988), whereas the matrix contains the calbindin protein (Gerfen et al., 1985), the cell bodies of cholinergic neurons (Graybiel et

\footnotetext{
Received Sept. 20, 1990; revised Dec. 3, 1990; accepted Dec. 5, 1990.

This study was supported by INSERM, by College de France, and by grants from Rhône-Poulenc santé.

Correspondence should be addressed to Marie-Odile Krebs, Chaire de Neuropharmacologie, INSERM U 1 14, Collège de France 11, place Marcelin Berthelot, 75231 Paris Cedex 05, France.

Copyright (C) 1991 Society for Neuroscience $0270-6474 / 91 / 111256-07 \$ 03.00 / 0$
}

al., 1986), and somatostatin interncurons (Chesselet and Graybiel, 1986). Moreover, the patterns of afferent fibers and efferent neurons are different in each compartment. For instance, limbicrelated systems provide major inputs to the striosomes, whereas neocortical areas favor the matrix (Gerfen, 1984; Donoghue and Herkenham, 1986; Malach and Graybiel, 1986). In addition, the organization of cortical inputs is related to their laminar origin (Gerfen, 1989): superficial layers project principally to the matrix and deeper layers to the striosomes. The striatal compartments also differ by their mesencephalic dopaminergic innervation. Nigral dopaminergic neurons issued from the "denso-cellular" zone of A9 project only to the striosomes, and A8 neurons only to the matrix, while the remaining A9 neurons project to both compartments (Gerfen et al., 1987; JimenezCastellanos and Graybiel, 1987). On the other hand, the substantia nigra pars compacta receives projections only from the striosomes, while the pars reticulata and the globus pallidus are innervated by the matrix (Gerfen, 1984; Desban et al., 1989; Jimenez-Castellanos and Graybiel, 1989).

As a result of this complex organization, the analysis of interactions between the corticostriatal glutamate- and/or aspartate-containing fibers and nerve terminals of the nigrostriatal dopaminergic neurons in both striatal compartments seemed to be of particular interest.

It is well established that the corticostriatal glutamatergic neurons exert a stimulatory effect on striatal neurons (Kitai et al., 1976) and are involved in the presynaptic regulation of dopamine (DA) release from nerve endings of nigrostriatal dopaminergic neurons (Nieoullon et al., 1978; Romo et al., 1986). Indeed, as shown in vitro in the rat (Giorguieff et al., 1977; Roberts and Anderson, 1979) or in vivo (at $10^{-8}$ or $10^{-7} \mathrm{M}$ ) in the cat (Chèramy et al., 1986), the application of glutamate increases the release of DA in the striatum. Previous experiments in vitro and in vivo have demonstrated that glutamatergic receptors of both quisqualate/kainate and NMDA types are involved in this regulation (Roberts and Anderson, 1979; Snell and Johnson, 1987; Carter et al., 1988; Clow and Jhamandas, 1989; Krebs et al., 1989; Ransom and Deschènes, 1989; Barbeito et al., 1990). Furthermore, as has been observed with both glutamate and kainate, the stimulatory effect of NMDA on DA release was found to be partly resistant to tetrodotoxin (TTX; Roberts and Anderson, 1979; Snell and Johnson, 1987; Clow and Jhamandas, 1989; Ransom and Deschènes, 1989; Krebs et al., 1991). In the presence of TTX, a voltage-dependent sodiumchannel blocker, indirect regulations, which involve other neurons or nerve terminals, are blocked, whereas direct regulations 
are resistant. NMDA-mediated regulation of DA release seems thus to be both indirect (TTX sensitive) and direct (TTX resistant). The presence of NMDA receptors on the dopaminergic nerve terminals themselves was recently confirmed on purified rat striatal synaptosomes (Krebs et al., 1991).

Using a new in vitro microsuperfusion device, which allows the estimation of DA release from restricted areas of the rat striatum (Krebs et al., 1989), we have previously noticed variations in the amplitude of the NMDA-evoked responses. The aim of this study was to determine whether or not these variations could be related to striatal compartmentalization, as reported recently for the cholinergic presynaptic regulation in the cat caudate nucleus (Kemel et al., 1989). We have thus investigated the NMDA receptor-mediated presynaptic regulation of DA release in striosome- and matrix-enriched areas, defined on the basis of the compartmentalization of $\mu$-opiate receptors on both coronal and sagittal rat striatal sections. Our results provide further evidence for a functional relevance of the anatomically described heterogeneity of the striatum.

\section{Materials and Methods}

Autoradiography of ${ }^{3} \mathrm{H}$-naloxone on $\mu$-opiate binding sites. ${ }^{3} \mathrm{H}$-naloxone binding sites were visualized according to a procedure previously described by Trovero et al. (1990), adapted from Herkenham and Pert (1982). Briefly, male Sprague-Dawley rats were killed, and the brains were rapidly removed and frozen in isopentane at $-40^{\circ} \mathrm{C}$. Sections $(20$ $\mu \mathrm{m})$, cut with a cryostat at $-20^{\circ} \mathrm{C}$ and mounted onto gelatin-coated glass slides, were incubated for $60 \mathrm{~min}$ at $4^{\circ} \mathrm{C}$ with $2 \mathrm{nM}{ }^{3} \mathrm{H}$-naloxone (56.1 Ci/mmol; Amersham) in Tris- $\mathrm{HCl}$ buffer $(50 \mathrm{~mm}, \mathrm{pH} 7.4,100$ $\mathrm{mm} \mathrm{NaCl}$ ). Nonspecific binding was determined with $10 \mu \mathrm{M}$ morphine. After five washes ( $2 \mathrm{~min}$ each) with ice-cold $50-\mathrm{mm}$ Tris- $\mathrm{HCl}$ buffer, sections were dried and apposed to ${ }^{3} \mathrm{H}$-Ultrofilm (LKB) during 8 weeks at $4^{\circ} \mathrm{C}$.

Estimation of ${ }^{3} \mathrm{H}-\mathrm{DA}$ release in striosome- and matrix-enriched areas of the rat striatum. As previously described (Krebs et al., 1989), brains of male Sprague-Dawley rats (250-300 gm; Charles River, France) were rapidly removed and cooled, and thick slices $(1 \mathrm{~mm})$ were cut using a vibratome. Appropriate slices were then placed in a superfusion chamber in a continuously renewed $\mathrm{Mg}^{2+}$-free artificial cerebrospinal fluid $\left(\mathrm{CSF} ; 34^{\circ} \mathrm{C}\right.$, saturated with $\mathrm{O}_{2} / \mathrm{CO}_{2}, 95: 5 \mathrm{v} / \mathrm{v}$ ). Onto each of the selected areas (see Fig. 1), a microsuperfusion device was placed vertically, and $\mathrm{Mg}^{2+}$-free CSF containing $\mathrm{L}-3,5-{ }^{3} \mathrm{H}$-tyrosine $(60 \mu \mathrm{Ci} / \mathrm{ml})$ was continuously delivered $(50 \mu \mathrm{l} / \mathrm{min})$ through each device. After a prelabeling period $(40 \mathrm{~min})$, the release of newly synthesized ${ }^{3} \mathrm{H}-\mathrm{DA}$ was estimated in superfusates collected in successive 5 -min fractions, ${ }^{3} \mathrm{H}-\mathrm{DA}$ being separated from ${ }^{3} \mathrm{H}$-tyrosine and ${ }^{3} \mathrm{H}$-metabolites by ion-exchange chromatography and alumina adsorption (Nieoullon et al., 1978).

When added, $\mathrm{Mg}^{2+}(1 \mathrm{mM}),(+)-5$-methyl-10,11-dihydro-5H-dibenzo(a,d)cyclohepten-5,10-imine maleate (MK-801; $1 \mu \mathrm{M})$, TTX $(1 \mu \mathrm{M})$, or strychnine $(1 \mu \mathrm{M})$ were present throughout the superfusion, while NMDA $(50$ or $100 \mu \mathrm{M})$, glycine $(1$ or $100 \mu \mathrm{M})$, or kynurenate $(100 \mu \mathrm{M})$ were applied $65 \mathrm{~min}$ after the beginning and remained applied up to the end of the superfusion.

The evoked release of ${ }^{3} \mathrm{H}-\mathrm{DA}$ was expressed as a percentage of the average spontaneous release, estimated in the first four fractions. Results are the means \pm SEM of data obtained in 6-12 experiments. Differences between treatments were evaluated with Student's $t$ test; level for significance was $p<0.05$.

$\mathrm{L}-3,5-{ }^{3} \mathrm{H}$-tyrosine $(50 \mathrm{Ci} / \mathrm{mmol})$ was purchased from New England Nuclear or Commissariat à l'Energie Atomique (France). MK-801 was a gift from Merck-Sharp and Dohme. Other compounds were purchased from Sigma.

Autoradiographic control of the diffusion and the volume of the superfusion. At the end of each experiment, slices were washed with fresh $\mathrm{CSF}$, dried at room temperature, and exposed to ${ }^{3} \mathrm{H}$-Ultrofilm (LKB) during various times (4-24 hr). Autoradiograms indicated that the labeling was restricted to the tissue located under the superfusion device (see Fig. 1). In some cases, after the experiments, the slices were included in an embedding resin (Ystosystem, RUA Instruments), and longitudinal sections were cut and exposed in the same conditions. The radio- activity was limited to a half-spherical volume that did not reach the opposite side of the slice. The volume of labeled tissue was thus estimated to be approximately $1 \mathrm{~mm}^{3}$.

\section{Results}

Localization of striosomal and matrix compartments on coronal and sagittal brain sections

Visualization by autoradiography of ${ }^{3} \mathrm{H}$-naloxone binding on $\mu$-opiate receptors, the best striosome-specific marker in the rat striatum, was performed on coronal and sagittal brain sections $(20 \mu \mathrm{m})$. In agreement with previous reports (Herkenham and Pert, 1981; Mansour et al., 1987; Tempel and Zukin, 1987; Sharif and Hughes, 1989), ${ }^{3} \mathrm{H}$-naloxone binding cxhibitcd a patchy distribution, with highly labeled striosomes contrasting with the weakly labeled matrix. Labeled patches were very numerous on anterior coronal slices of the striatum [anteriority (A), $11.6>\mathrm{A}>10.6$, according to the atlas of Paxinos and Watson, 1986], covering approximately $50 \%$ of the striatal tissue (at $\mathrm{A}=11.0 ;$ Fig. 1). In contrast, beyond the anteriority of 9.4, labeled patches were very sparse, and the unlabeled tissue represented more than $80 \%$ of the striatum.

On sagittal sections, the most lateral brain sections revealed the existence of a pure unlabeled matrix area with only a thin labeled border [laterality (L), >3.9], whereas medial slices $(\mathrm{L}<$ 2.4) exhibited many patches, especially near the anterior border.

Thus, striosome-enriched areas can be defined on anterior coronal slices and medial sagittal sections, which comprise many striosomes. Matrix-enriched areas are located on posterior coronal scetions and latcral sagittal scctions. These zones being large enough, the analysis of the NMDA-mediated regulation of DA release was undertaken in each of these zones on both sagittal and coronal sections.

\section{NMDA-evoked release of ${ }^{3} H-D A$ in striosome- and matrix-enriched areas}

In all areas, NMDA $(50 \mu \mathrm{M})$ increased the release of newly synthesized ${ }^{3} \mathrm{H}-\mathrm{DA}$ from the dopaminergic nerve terminals (Fig. 2 ). However, the amplitude of the response was different in striosomal than in matrix areas. In anterior (coronal slices) and medial (sagittal slices) striosome-enriched zones, the NMDAevoked release of ${ }^{3} \mathrm{H}-\mathrm{DA}$ during the first $5 \mathrm{~min}$ was only 171 $\pm 6 \%$ and $161 \pm 6 \%$ of the spontaneous release, respectively. In the posterior matrix-enriched area (frontal slices), NMDA induced a significantly higher response $(223 \pm 6 \%$ of the spontaneous release), approaching the response obtaincd in the lateral matrix area (sagittal slices; $248 \pm 12 \%$ ). In all cases, the maximal NMDA-evoked release of ${ }^{3} \mathrm{H}-\mathrm{DA}$ was observed during the first $5 \mathrm{~min}$ of NMDA application. Thereafter, ${ }^{3} \mathrm{H}-\mathrm{DA}$ release declined progressively, but the evoked response represented still about $50 \%$ of the maximal value at the end of the $25-\mathrm{min}$ NMDA application.

When a higher dose of agonist was used $(100 \mu \mathrm{M})$, the responses were increased, but the difference between striosomal and matrix areas remained $(203 \pm 17 \%$ and $266 \pm 10 \%$ of the spontaneous release on medial and lateral sagittal slices, respectively).

\section{Pharmacological characterization of NMDA-evoked release of} ${ }^{3} \mathrm{H}-\mathrm{DA}$ in striosome- and matrix-enriched areas

Confirming our previous results (Krebs et al., 1989), all NMDAevoked responses were blocked by either MK-801 $(1 \mu \mathrm{M})$ or $\mathrm{Mg}^{2+}$ (1 mM; Fig. 3). 

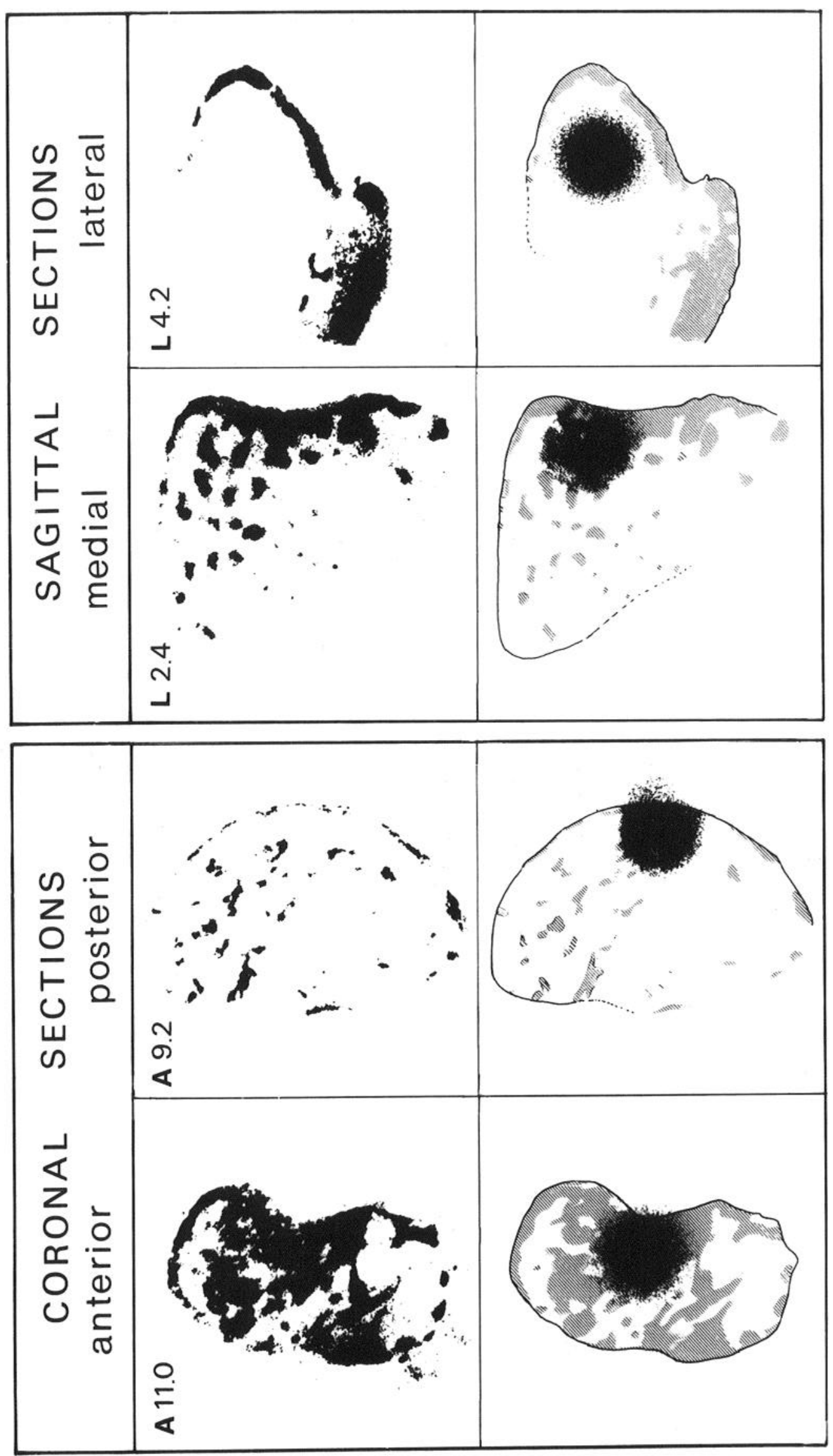

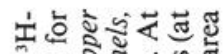

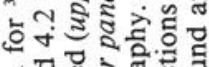

उृ

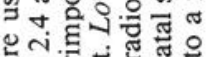

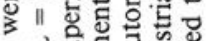

है

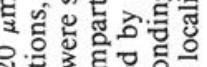

论

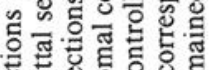

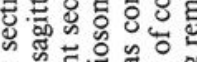

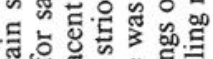

的要㔖

동. 8.0

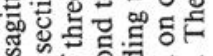

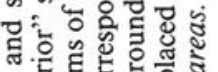

別紫

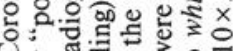

눙의의

尫

긍

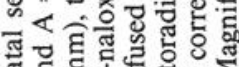

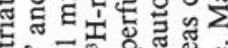

管

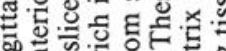

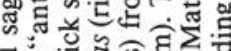

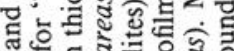

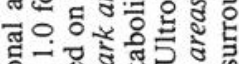

ㅊ.

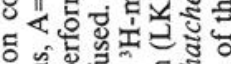

吅兔

\$.

论

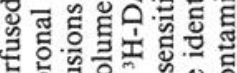

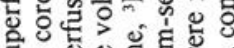

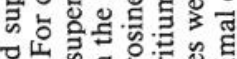

난

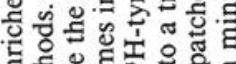

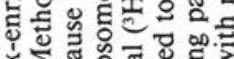

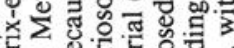

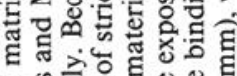

궁영

न

छั ${ }^{\circ}$.

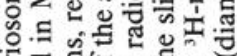

政.

数忽券

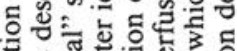

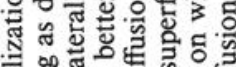

에류

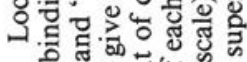

-

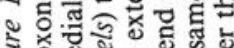

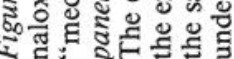




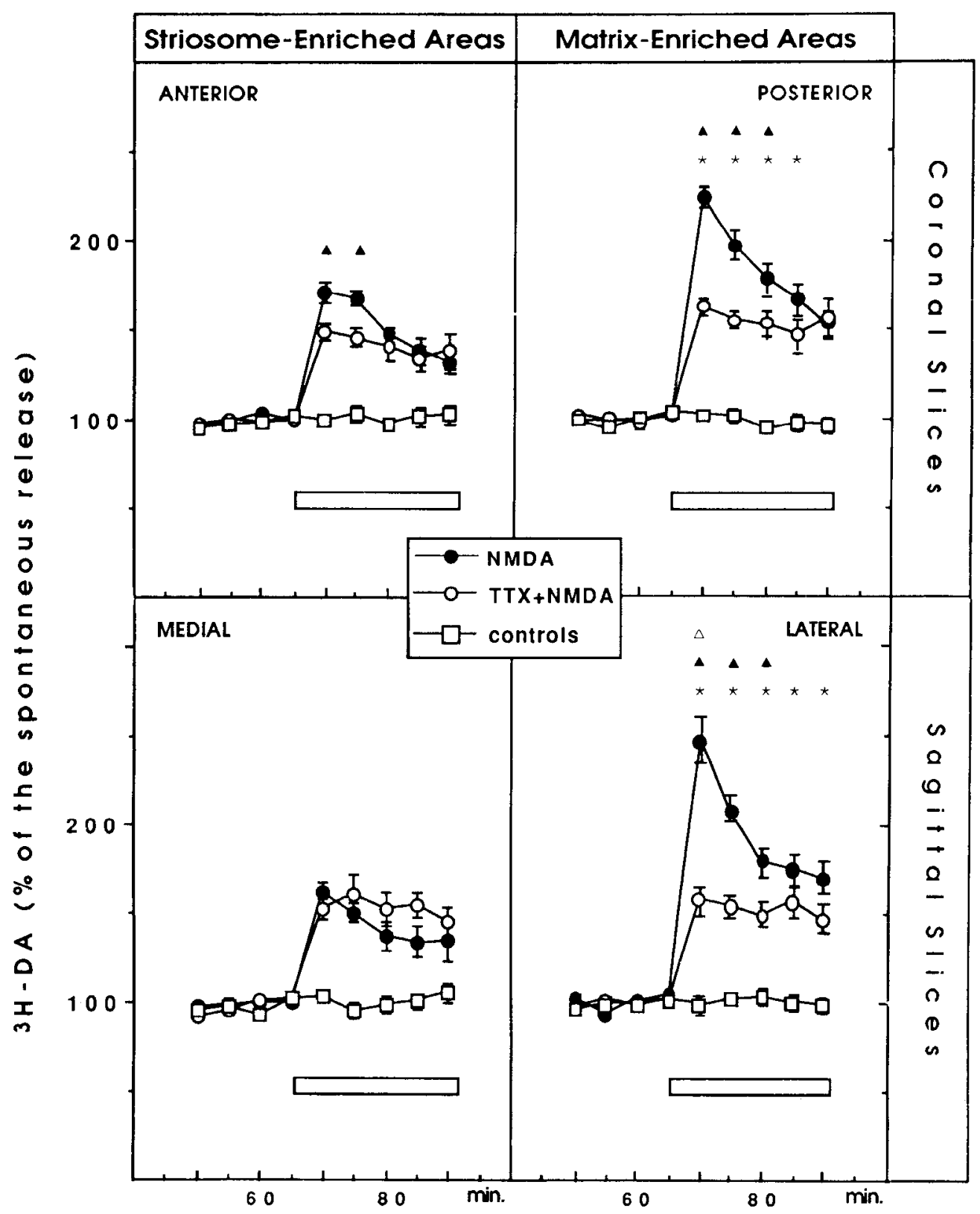

Figure 2. TTX-resistant and -sensitive NMDA-evoked release of ${ }^{3} \mathrm{H}-\mathrm{DA}$ in striosome- and matrix-enriched areas. Experiments were performed on rat coronal and sagittal striatal slices as described in Materials and Methods. NMDA $(50 \mu \mathrm{M})$ was added for $25 \mathrm{~min}$ (open bars), $65 \mathrm{~min}$ after the beginning of the superfusion with the ${ }^{3} \mathrm{H}$-tyrosineenriched $\mathrm{Mg}^{2+}$-free medium. TTX (1 $\mu \mathrm{M})$, when used, was present throughout the superfusion. The release of ${ }^{3} \mathrm{H}$ DA was estimated in 5-min fractions and expressed as the percentage of the average spontaneous release determined during the first four fractions. Results are the means \pm SEM of data obtained in 10-18 experiments. Basal spontaneous ${ }^{3} \mathrm{H}-\mathrm{DA}$ releases in the 4 zones were not significantly different. In all the cases, the values of NMDA- or TTX + NMDA-evoked responses were significantly different from their respective controls, even for the last point. $(\Delta, p<0.05$, significance of the NMDA effect when compared to the NMDA + TTX response; *, $p<0.05$, significance of the NMDA effect in matrix areas when compared to striosomal areas; $\triangle$, $p<0.05$, significance of the NMDA effect in the lateral matrix area when compared to that found in the posterior matrix area.
We have also previously shown that the NMDA-evoked release of ${ }^{3} \mathrm{H}$-DA is potentiated by glycine, which acts on the strychnine-insensitive site of the NMDA receptor, while kynurenate (an endogenous antagonist of this site; Kessler et al., 1989) blocks that effect of NMDA (Krebs et al., 1989). Under our conditions, probably due to the high flow rate of the superfusion, the glycine sites were not saturated by endogenous glycine, because the potentiating effect of glycine $(1 \mu \mathrm{M})$ on NMDA response was seen directly. Experiments were performed in order to analyze whether or not the differences in the magnitude of the responses observed between striosome- and matrix-enriched areas could be due to regional variations in the concentration of endogenous agonists (glycine, D-serine, etc.) or antagonists (kynurenate). The effect of the coapplication of glycine $(1 \mu \mathrm{M})$ and NMDA $(50 \mu \mathrm{M})$ in the presence of strychnine was first examined. In all areas, the NMDA-evoked response was potentiated (Fig. 3): $250 \pm 20 \%$ and $213 \pm 15 \%$ of the spontaneous release in the striosome-enriched areas of anterior and medial slices, respectively; $367 \pm 23 \%$ and $369 \pm 34 \%$ in the matrix-enriched areas of posterior and lateral slices, respectively. Nevertheless, the NMDA-evoked release of ${ }^{3} \mathrm{H}$-DA in striosome-enriched areas did not reach the level found in matrix-enriched zones, even when a higher concentration of glycine $(100 \mu \mathrm{M})$ was used: $249 \pm 28 \%$ and $204 \pm 16 \%$ in anterior and medial striosome-enriched areas, respectively; 290 $\pm 20 \%$ and $307 \pm 50 \%$ in posterior and lateral matrix-enriched areas, respectively. In addition, kynurenate $(100 \mu \mathrm{M})$ almost totally blocked the NMDA-evoked release of ${ }^{3} \mathrm{H}-\mathrm{DA}$, suggesting that in the four zones examined endogenous glycine partially occupies the glycine modulatory sites on the NMDA receptors.

\section{$T T X$-resistant $N M D A$-evoked release of ${ }^{3} H-D A$ in striosome- and matrix-enriched areas}

Additional experiments were performed in the presence of TTX $(1 \mu \mathrm{M})$ in order to distinguish direct and indirect presynaptic regulations of DA release in each area. In agreement with pre- 


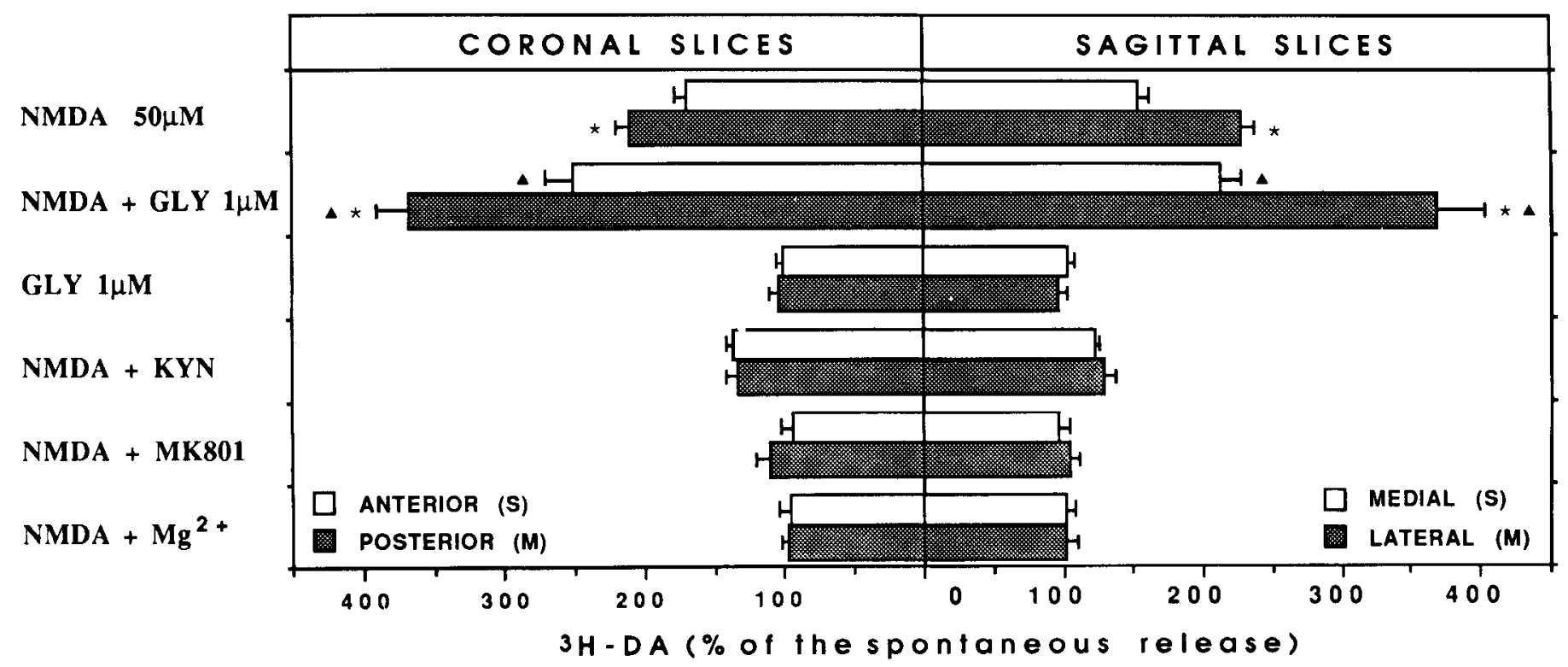

Figure 3. Characterization of the NMDA-evoked release of ${ }^{3} \mathrm{H}-\mathrm{DA}$ in striosome- and matrix-enriched areas. Experiments were performed on rat coronal and sagittal slices as described in Materials and Methods and in Figure 2. Results are expressed as the percentage \pm SEM of the spontaneous release of ${ }^{3} \mathrm{H}$-DA estimated during the first four fractions before NMDA and/or glycine application. Values are the mean of the evoked release of ${ }^{3} \mathrm{H}$-DA estimated in the first two fractions following the application of the agonist. Glycine experiments were performed in the presence of strychnine $(1 \mu \mathrm{M}) . M K-801(1 \mu \mathrm{M}), M g^{2+}(1 \mathrm{mM})$, or strychnine were added from the beginning into the superfusion medium; $N M D A(50 \mu \mathrm{M})$, glycine $(G L Y$; $1 \mu \mathrm{M})$ or kynurenate $(K Y N ; 100 \mu \mathrm{M})$ were added after $65 \mathrm{~min}$. Results are the mean of data obtained in $6-12$ experiments. In all the cases, NMDAor NMDA + glycine-evoked responses were significantly different from their respective controls $(p<0.05)$. The blockade of NMDA-evoked responses by kynurenate, MK-801, or $\mathrm{Mg}^{2+}$ in the four areas were significant. $(\Lambda, p<0.05$, significance of the NMDA + glycine effect when compared to the NMDA-evoked response; ${ }^{*}, p<0.05$, significance of the NMDA effect in matrix areas when compared to that observed in striosomal areas.

vious results (Krebs et al., 1991), NMDA could still increase the release of ${ }^{3} \mathrm{H}-\mathrm{DA}$ in the presence of TTX (Fig. 2). In fact, the NMDA-evoked response had similar maximal amplitude in the four selected zones: $148 \pm 5 \%$ and $161 \pm 5 \%$ in the anterior and posterior zones of coronal slices, respectively; 152 $\pm 8 \%$ and $156 \pm 7 \%$ in the medial and lateral zones of sagittal sections, respectively. Contrasting with results obtained in the absence of TTX, no significant decline in ${ }^{3} \mathrm{H}-\mathrm{DA}$ release was seen during the 25-min NMDA application.

Thus, in striosome-enriched areas, the effect of NMDA was almost totally resistant to TTX, while in matrix areas, it was diminished by more than half (particularly in sagittal sections), suggesting that the indirect component of the stimulating effect of NMDA on DA release is more important in the matrix areas.

\section{Discussion}

Regional variations have often been described in pharmacological studies performed in the rat striatum, but their relation to the anatomical compartmentalization has never been demonstrated. Due to the very small size of rat striosomes, pharmacological analysis of pure striosomal striatal tissue is not conceivable. We thus had to define areas enriched in striosomes or matrix. This was done in both coronal and sagittal brain sections, on the basis of ${ }^{3} \mathrm{H}$-naloxone binding-site autoradiography, the best striosome-specific marker in the rat striatum (Herkenham and Pert, 1981). Because our experimental device allows the superfusion of restricted areas, we were thus able to compare the NMDA-evoked release of ${ }^{3} \mathrm{H}-\mathrm{DA}$ not only between anterior and posterior or medial and lateral parts of the striatum, but between striosome- and matrix-rich striatal areas in each of the four selected slices. Even though these areas were not pure, the good concordance of the results obtained between the two striosomal areas or the two matrix areas validates this distinction. However, differences in the responses between the two matrix or the two striosomal areas were seen, especially in the matrix, though these did not reach significance (except for the first fraction of NMDA-evoked response in matrix areas; Fig. 2). Several explanations can be given: (1) the two section planes (sagittal or coronal) might have led to differential lesions of the afferents; (2) matrix and striosomal superfused areas seemed more "pure" with sagittal than with coronal slices; (3) anatomical and functional heterogeneity of the matrix has been reported (Malach and Graybiel, 1986; Desban et al., 1989); and (4) besides the striosome/matrix organization, other factors of topographical heterogeneity may exist because, for instance, dopaminergic and cholinergic agents have been shown to modify differently the in vivo release of ${ }^{3} \mathrm{H}-\mathrm{GABA}$ in the rat striatum when applied in either the dorsal or the ventral part of the structure (Girault et al., 1986).

As already emphasized, glutamatergic presynaptic regulation of DA release from nerve terminals of nigrostriatal neurons has been fully demonstrated (Giorguieff et al., 1977; Roberts and Anderson, 1979; Chèramy et al., 1986), and the role of NMDA receptors has been characterized previously (Snell and Johnson, 1987; Carter et al., 1988; Clow and Jhamandas, 1989; Krebs et al., 1989; Ransom and Deschènes, 1989). According to autoradiographic studies, the striatum contains a large density of NMDA receptors, but their repartition is heterogeneous (Monaghan and Cotman, 1985). Nevertheless, a preferential localization of these receptors in the striosomes or the matrix has 
not yet been demonstrated. We now report that the NMDAevoked release of DA is greater in matrix than in striosomal zones.

Allosteric modulators acting on the glycine site of the NMDA receptor, such as glycine or kynurenate (Moroni et al., 1988), are found endogenously and modulate its function. Differences in this modulation between the two compartments could help to illuminate some of the mechanisms of neurodegenerative disorders, because NMDA receptor-mediated neurotoxicity has been implicaled in some cases (Beal et al., 1986; Rothman and Olney, 1987; Choi et al., 1988; Young et al., 1988). However, the difference in amplitude of the NMDA-evoked release of DA between the two compartments does not seem to be related to regional variations in the concentrations of glycine/kynurenate, because at saturating concentrations of glycine ( 1 and $100 \mu \mathrm{M}$, in the presence of $1 \mu \mathrm{M}$ strychnine), responses in the striosomeenriched zones still remained lower than those found in matrix areas.

TTX-resistant NMDA-evoked responses were not significantly different in the two compartments. Because TTX blocks most indirect regulations, these results suggest that the direct presynaptic regulation of DA release, which involves presynaptic NMDA receptors located on dopaminergic nerve terminals, is similar in striosomes and matrix. In contrast, indirect mechanisms, involving intrinsic striatal neurons or other afferent fibers, seem to play a more important role in the matrix, because marked differences were seen between the NMDAevoked responses in the absence or presence of TTX in matrixenriched areas.

The mechanisms of the modulation by corticostriatal fibers of DA release from nerve terminals of nigrostriatal neurons mediated by NMDA receptors thus seem distinct in the striosomes and in the matrix. Such a functional difference between the two compartments has already been demonstrated in our laboratory for the cholinergic presynaptic regulation of DA release in the cat caudate nucleus. Indeed, this regulation is more complex in the matrix, involving indirect excitatory and inhibitory regulations through muscarinic and nicotinic cholinergic receptors, respectively (Kemel et al., 1989). In addition, a heterogeneity in the indirect inhibitory cholinergic regulation of DA release has also been demonstrated, because this inhibitory effect can be blocked cither by naloxone or by bicucullinc, depending on the matrix area superfused (Gauchy et al., 1991).

The compartmentalization in striosomes and matrix seems to be of crucial importance in explaining how the striatum can process information as different as that mediated by limbic and sensorimotor inputs. This hypothesis, corroborated by the segregation of input/output systems, thus finds further support with the demonstration of functional differences between the two striatal compartments.

\section{References}

Barbeito L, Chèramy A, Godeheu G, Desce JM, Gluwinski J (1990) Glutamate receptors of the quisqualate-kainate subtype are involved in the presynaptic regulation of the dopamine release in the cat caudate nucleus in vivo. Eur J Neurosci 2:304-311.

Beal MF, Kowall NW, Ellison DW, Mazurek MF, Schwartz KJ, Martin JB (1986) Replication of the neuroanatomical characteristics of Huntington's disease by quinolinic acid. Nature 321:168-171.

Carter CJ, L'Heureux R, Scatton B (1988) Differential control by $N$-methyl-D-aspartate and kainate of striatal dopamine release in vivo: a trans-striatal dialysis study. J. Neurochem 51:462-468.

Chèramy A, Romo R, Godeheu G, Baruch P, Glowinski J (1986) In vivo presynaptic control of dopamine release in the cat caudate nucleus. II: Facilitatory or inhibitory influence of $L$-glutamate. Neuroscience 19:1081-1090.

Chesselet MF, Graybiel AM (1986) Striatal neurons expressing somatostatin-like immunoreactivity: evidence for a peptidergic interneuronal system in the cat. Neuroscience 17:547-571.

Choi DW, Koh JY, Peters S (1988) Pharmacology of glutamate neurotoxicity in cortical cell culture: attenuation by NMDA antagonists. J Neurosci 8:185-196.

Clow DW, Jhamandas K (1989) Characterization of L-glutamate action on the release of endogenous dopamine from rat caudate-putamen. J Pharmacol Exp Ther 248:722-728.

Desban M, Gauchy C, Kemel ML, Besson MJ, Glowinski J (1989) Three-dimensional organization of the striosomal compartment and patchy distribution of striatonigral projections in the matrix of the cat caudate nucleus. Neuroscience 29:551-566.

Donoghue JS, Herkenham M (1986) Neostriatal projections from individual cortical fields conform to histochemically distinct striatal compartments in the rat. Brain Res 365:397-403.

Gauchy C, Desban M, Krebs MO, Glowinski J, Kemel ML (1991) Role of dynorphin-containing neurons in the presynaptic inhibitory control of the acetylcholine-evoked release of dopamine in the striosomes and the matrix of the cat caudate nucleus. Neuroscience, in press.

Gerfen CR (1984) The neostriatal mosaic: compartmentalization of corticostriatal input and nigrostriatal output systems. Nature 311: $461-464$.

Gerfen CR (1989) The neostriatal mosaic: striatal patch-matrix organization is related to cortical lamination. Science 246:385-387.

Gerfen CR, Baimbridge KG, Miller JJ (1985) The neostriatal mosaic: compartmental distribution of calcium-binding protein and parvalbumin in the basal ganglia of the rat and monkey. Proc Natl Acad Sci USA 82:8780-8794.

Gerfen CR, Herkenham M, Thibault J (1987) The neostriatal mosaic: II. Patch- and matrix-directed mesostriatal dopaminergic and nondopaminergic systems. J Neurosci 7:3915-3934.

Giorguieff MF, Kemel ML, Glowinski J (1977) Presynaptic effect of L-glutamic acid on the release of dopamine in rat striatal slices. Neurosci Lett 6:73-77.

Girault JA, Spampinato U, Savaki HE, Glowinski J, Besson MJ (1986) In vivo release of $\left[{ }^{3} \mathrm{H}\right] \gamma$-aminobutyric acid in the rat neostriatum-I. Characterization and topographical heterogeneity of the effects of dopaminergic and cholinergic agents. Neuroscience 19:1101-1108.

Graybiel AM, Ragsdale CW Jr (1978) Histochemically distinct compartments in the striatum of human, monkey and cat demonstrated by acetylthiocholinesterase staining. Proc Natl Acad Sci USA 75: 5723-5727.

Graybiel AM, Baughman RW, Eckenstein F (1986) Cholinergic neuropil of the striatum observes striosomal boundaries. Nature 323: 625-627.

Herkenham M, Pert CB (1981) Mosaic distribution of opiate receptors, parafascicular projections and acetylcholinesterase in rat striatum. Nature 291:415-418.

Herkenham M, Pert CB (1982) Light microscopic localization of brain opiate receptors: a general autoradiographic method which preserves tissue quality. J Neurosci 2:1129-1149.

Jimenez-Castellanos J, Graybiel AM (1987) Subdivisions of the dopamine-containing A8-A9-A10 complex identified by their differential mesostriatal innervation of striosomes and extrastriosomal matrix. Neuroscience 23:223-242.

Jimenez-Castellanos J, Graybiel AM (1989) Compartmental origins of striatal efferent projections in the cat. Neuroscience 32:297-321.

Kemel ML, Desban M, Glowinski J, Gauchy C (1989) Distinct presynaptic control of dopamine release in striosomal and matrix areas of the cat caudate nucleus. Proc Natl Acad Sci USA 86:9006-9010.

Kessler M, Terramani T, Lynch G, Baudry M (1989) A glycine site associated with NMDA receptors: characterization and identification of a new class of antagonists. J Neurochem 52:1319-1328.

Kitai ST, Kocsis JD, Preston RJ, Sugimori M (1976) Monosynaptic inputs to caudate nucleus identified by intra-cellular injection of horseradish peroxidase. Brain Res 109:601-606.

Krebs MO, Kemel ML, Gauchy C, Desban M, Glowinski J (1989) Glycine potentiates the NMDA-induced release of dopamine through a strychnine-insensitive site in the rat striatum. Eur J Pharmacol 166: $567-570$. 
Krebs MO, Desce JM, Kemel ML, Gauchy C, Godeheu G, Chèramy A, Glowinski J (1991) Glutamatergic control of dopamine release in the rat striatum: evidence for presynaptic NMDA receptors on dopaminergic nerve terminals. J Neurochem 56:81-85.

Malach R, Graybiel AM (1986) Mosaic architecture of somatic sensory-recipient sector of the cat's striatum. J Neurosci 6:3436-3458.

Mansour A, Khachaturian H, Lewis ME, Akil II, Watson SJ (1987) Autoradiographic differentiation of mu, delta and kappa opioid receptors in the rat forebrain and midbrain. J Neurosci 7:2445-2464.

Monaghan DT, Cotman CW (1985) Distribution of $N$-methyl-D-aspartate-sensitive $\mathrm{L}^{-3} \mathrm{H}$-glutamate-binding sites in rat brain. J Neurosci 5:2909-2919.

Moroni F, Russi P, Lombardi G (1988) Presence of kynurenic acid in the mammalian brain. J Neurochem 51:177-180.

Nastuk MA, Graybiel AM (1988) Autoradiographic localization and biochemical characteristics of M1 and M2 muscarinic binding sites in the striatum of the cat, monkey and human. J Neurosci 8:10521062.

Nieoullon A, Chèramy A, Glowinski J (1978) Release of dopamine evoked by electrical simulation of the motor and visual areas of the cerebral cortex in both caudate nuclei and in the substantia nigra in the cat. Brain Res 145:69-83.

Paxinos G, Watson C (1986) The rat brain in stereotaxic coordinates. London: Academic.

Ransom RW, Deschènes NL (1989) Glycine modulation of NMDAevoked release of $\left[{ }^{3} \mathrm{H}\right]$ acetylcholine and $\left[{ }^{3} \mathrm{H}\right]$ dopamine from rat striatal slices. Neurosci Lett 96:323-328.
Roberts PJ, Anderson SD (1979) Stimulatory effect of L-glutamate and related amino acids on ${ }^{3} \mathrm{H}$-dopamine release from rat striatum: an in vitro model for glutamate actions. $J$ Neurochem 32:1539-1545.

Romo R, Chèramy $\mathrm{A}$, Godeheu $\mathrm{G}$, Glowinski J (1986) In vivo presynaptic control of dopamine release in the cat caudate nucleus-III Further evidence for the implication of corticostriatal glutamatergic neurons. Neuroscience 19:1091-1099.

Rothman SM, Olney JW (1987) Excitotoxicity and the NMDA receptor. Trends Neurosci 10:299-302.

Sharif NA, Hughes J (1989) Discrete mapping of brain mu and delta opioid receptors using selective peptides: quantitative autoradiography, species differences and comparison with kappa receptors. Peptides 10:499-522.

Snell LD, Johnson KM (1987) Characterization of the inhibition of excitatory amino acid-induced neurotransmitter release in the rat striatum by phencyclidine-like drugs. J Pharmacol Exp Ther 238: 938-946.

Tempel A, Zukin RS (1987) Neuroanatomical patterns of the $\mu, \delta$ and $\kappa$ opioid receptors of the rat brain as determined by quantitative in vitro autoradiography. Proc Natl Acad Sci USA 84:4308-4312.

Trovero F, Ilerve D, Desban M, Glowinski J, Tassin JP (1990) Striatal opiate mu-receptors are not located on dopamine nerve endings in the rat. Neuroscience 39:313-321.

Young AB, Greenamyre JT, Hollingsworth Z, Albin R, D'Amato C, Shoulson I, Penney JB (1988) NMDA receptor losses in putamen from patients with Huntington's disease. Science 241:981-983. 